\title{
PENA Y ESTADO
}

\section{Juan Bustos Ramírez y Hernán Hormazábal Mallaré (Universidad de Barcelona)}

Con este estudio se pretende analizar y porer de maniffesto la directa relación que existe entre una determinada forma de Estado y el tipo y carácter de la pena con la que éste sanciona los comportamientos que él mismo define como criminales. Para ello se realiza una exposición de la evolución y desarrollo histórico del Estado partiendo del Estado absolutista y terminando con el de nuestros días. Paralelamente se analiza el carácter otorgado a la pena por las sucesivas formas que ba adoptado en su desarroIlo el Estado capitalista. De todo ello se desprende una lógica dependencia entre Estado y pena. En el último apartado se plantea la problemática Estado democrático y pena, es decir, la que según los autotes se planteatía sobre estas cuestiones en una posible sociedad realmente democrática. 


\section{EVOLUCION DEL ESTADO Y DE LA PENA}

La pena, su sentido, funciones y finalidad no puede entenderse si al mismo tiempo no se la analiza dentro de un sistema socio-económico y la forma de Estado imperante. Este trabajo, sin embargo, se centratá fundamentalmente en la relación entre Estado y pena. La existente entre pena (su ejecución) y estructura socioeconómica ha sido desarrollada por Rusche y Kirchheimer. ${ }^{1}$

Dentro de la concepción de un Estado absoluto, no limitado como el Estado feudal, ${ }^{2}$ basado sobre una estructura social de dependencia personal, cuya máxima expresión es justamente la identidad de soberano y Estado, aparecía evidente la unidad entre la moral y el Derecho, entre el Estado y la religión, y que el poder estuviese entregado por Dios directamente al soberano. Por tanto, la ley del soberano se confundía con la ley natural o dada por Dios. En el soberano radica el Estado y necesariamente el poder legal y de justicia. La pena se concibe como un castigo, como la expiación del mal (o pecado); se pena a quien se ha rebelado contra el soberano (que sería lo mismo que contra Dios). ${ }^{3}$ Se está, en último término,

1. Véase: «Sozialstruktur und Strafvolizug", 1974, Europäische Verlagsanstalt.

2. Nicos Poulantzas: «Poder Político y clases sociales en el Estado capitalista», 1976, Siglo XXI. Cfr. pp. 197 y ss.

3. La teoría del derecho divino de los reyes se basó en forma especial en la epístola de San Pablo a los romanos: «1. Todos han de estar sometidos a las autoridades superiores, pues no hay autoridad sino bajo Dios; y las que hay, por Dios hann sido establecidas. 2. De suerte que quien resiste a la autoridad, resiste a la disposición de Dios, y los que la resisten se atraen sobre sí la condenación. 3. Porque los magistrados no son de temer para los que obran bien, sino para los que obran mai. ¿Quieres vivir sin temor a la autoridad? Haz el bien y tendrás su aprobación. 4. Porque es ministro de Dios para el bien. Peto si haces el mal, teme, que no en vano Ileva la espada. Es ministro de Dios, vengador para castigo del que obra mal. 5. Es preciso someterse no sóło por temor del castigo, sino por conciencia. 6. Por tanto, pagadles los tributos, que son ministros de Dios ocupadios en eso. 7. Pagad a todos lo que debáis; a quien tributo, tributo; a quien aduana, aduana; a quien temor, temor; a quien honor, honor.s (XIII 1-7). 
ante las imágenes del ángel caído y de Adán expulsado del Paraíso. Esto es, no se pone en duda y no hay posibilidad de discutit que el Estado $\rightarrow y$ con ello el soberano- tiene tal potestad de imponer penas. El fundamento general de tal potestad aparece evidente. En cuanto al fundamento específico o individual, éste no es otro que el reconocimiento del hombre becbo a semejanza de Dios; lo que se castiga es su rebelión en contra del soberano y del Estado, de Dios en último término. ${ }^{5}$ El Estado absoluto viene a constituir el estadio necesario entre la sociedad de la Baja Edad Media y la sociedad liberal; esto es, permite el acelerado ascenso y desa* rrollo de la burguesía $y$, consecuentemente, la necesaria gran acumulación de capital. Por eso, con acierto se señala que el Estado absoluto es un Estado de transición. "La rápida expansión del comercio no podía adaptarse al sistema económico localista del feudalismo y un nuevo sistema bancario internacional comenzó a desarrollarse para satisfacer las crecientes necesidades del comercio. Con la aparición de los banqueros y comerciantes en cada país surgió una nueva clase, los burgueses, que no eran ni teyes ni aristócratas ni campesinos, ni podían ser incluidos entre los artesanos ni los comerciantes locales de los días del Medievo, ya que constituían un cuerpo independiente del cual dependerían en breve todas las demás clases, desde el tey hasta los siervos.»?

4. Al respecto es interesante to que señala Miaille respecto de la palabra Estado en Francia. «...La propia palabra "Estado" apareció en la lengua francesa en la época del absolutismo, esto es, hacia el siglo xv: y sería de uso generalizado desde el siglo xvir.» («L'État du droit», 1978, François Maspéro.)

5. Cfr. R.H.S. Crossman: «Biografía del Estado Moderno», 1977, Fondo de Cultura Economica, pp. 50 y ss., quien cira una frase paradigmática de Jacobo I de Inglaterra: «Los reyes son las imágenes vivientes de Dios» (p. S1). También cfr. PouIantzas, op. cit., pp. 204 y ss., quien con mucha claridad señaia ia diferencia entre Estado absoluto y feudal: «El Estado absolutista se caracteriza por el hecho de que el titular del poder estatal, por lo general un monarca, concentra en sus manos un poder incontrolable por las otras instituciones y cuyo ejercicio no es restringido por ninguna ley limitativa, ya sea esta ley de orden positivo a de orden natural-divino: el titular del poder es legibus solutus. Al contrario que el tipo de Estado feudal, en que el poder estatal está limitado a la vez por la ley divina - pues se considera el Estado como la manifestación đel orden cósmico-divino-_...) (p. 204).

6. Cfr. Miaille, op. cit., pp. 73 y ss., quien certeramente se pregunta: «¿Basado en qué se puede decir que el Estado absolutista realiza en Francia la acumulación primitiva de capital? Desde el principio descartemos una mala intexpretación: el capital que va a ser acumulado no es una suma de dinero, aun cuando aparezca al principio bajo esta forma. Es una relación social. En efecto, "detrás" de la apariencia de una masa de dinero y de mercancías, hay una realidad mucho más importante: la relación social gracias a la cual esas mcrcancías son producidas» (p. 73). Cfr. Dobb, Maurice; «Estudios sobre el desartollo del capitalismo", 1976, siglo xxI. pp. 109 y ss.; Poulantzas, op. cit., pp. 202 y ss.

7. Crossman, op. cit., p. 40 . 
El Estado absoluto implica una concentración total del poder y un uso ilimitado de él, necesario para el desarrollo posterior del capitalismo. En tal sentido, la pena no podia tener sino las misnnas características y constituir un medio más para realizar el objetivo capitalista. ${ }^{8}$ Es por ello que Rusche y Kirchheimer han destacado que, en este período, la ejecución de la pena consiste fundamentalmente en la explotación de la mano de obra: el sujeto es enviado a las galeras, a las colonias descubiertas o a las casas de trabajo (Rasphuis, Spinnhuis, Tutchthuis, Hôpitaux généraux), que no por una casualidad se desarrollan fundamentalmente en Holanda, Inglaterra y Alemania. Las casas de corrección o casas de trabajo, antecedente de la prisión y con ello el paralelo de la manufactura o fábrica, tuvie. ron por objetivo entregar mercancías a muy bajo precio y con ello promover la economía nacional. Así, al crearse la casa de corrección de Spandau en 1657, se señala que «el objeto de la institución era el de promover la producción de textiles y remediar la carencia de rueca en el país». Pero lo fundamental de la casa de trabajo, y por ello su subsistencia y transformación posterior en la cárcel, es el de convertir el trabajo también en una mercancía y, por tanto, constituirse en un instrumento de regulación del metcado de trabajo. ${ }^{10}$ Ciertamente resulta quizá más fácil indagar la relación entre ejecución de la pena y estructura socio-económica, pues es posible demostrar una interdependencia material directa. Pero ello no tesulta tan sencillo cuando se trata de la concepción de la pena (sentido, funciones y fines) y su legitimidad, pues entonces entra en juego una enmarañada red ideológica que impide su aprehensión directa y vela la interrelación entre estructura socio-económica y pena. De ahí que para desvelar dicha interrelación sea preferible primero ver la existente entre Estado y pena, como lo hemos hecho ya con el Estado absoluto, caracterizándolo como un Estado de transición al capitalismo. ${ }^{13}$

Con el mercantilismo empieza a desmoronarse la dependencia personal, rasgo característico de aquella estructura social, que va a ser sustituida por la dependencia de las cosas, por la diferencia entre capital y trabajo. ${ }^{11}$ bis Esto trae naturalmente consigo una revisión de la concepción del

8. Cfr, Dobb, M., op. cit., pp. 276 y ss., en la que señala toda la legislación que hubo en aquella época para mantener la afuencia de asalariados; Poulantzas, op. cit., pp. 209 y ss.; Rusche y Kirchheimer, «Sozialstruktur...», cit., pp. 36 y ss.

9. Rusche y Kirchheimer, op. cit., pp. 61 y ss. y 77 y ss. у 203.

10. Melossi, Dario, y Pavarini, Massimo: "Carcere e Frabbrica», pp. 201, 202

11. Como expresa Poulantzas: «La teoría del Estado capitalista no puede ser aislada de una bistoria de su constitución y de su reproducción» («Estado, Poder y Socialismo», 1978 , s. XXXI, p. 23).

11 bis, Cfr, Dobb, op. cit., pp. 249-250, en general 215 y ss. 
Estado: el Estado no puede estar ligado al sobetano ni a la persona de Dios, se trata de romper, pues, todas las ataduras personales, dependencia del señor, del gremio, del soberano, de Dios. Como dice Crossman: «Las revoluciones políticas se encuentran siempre al término de un proceso histórico. Llegan cuando los cambios económicos y sociales han sido tan notables que los viejos criterios y las viejas formas gubernamentales vienen a tesultar perfectamente inútiles. Entonces surgen nuevas filosofías, no al comienzo de un desarrollo, sino al finai... $\rangle^{12}$ Surge el Estado burgués, como expresión soberana del pueblo todo ${ }^{13}$-n el trasfondo está la teoría del contrato social-y con ello la división de poderes. Desaparecen los controles absolutos; éstos se hacen flexibles. ${ }^{14}$ "La gran revolución de 1789 . 1848 fue el triunfo no de la "industria" como tal, sino de la industria "capitalista"; no de la libertad y la igualdad en general, sino de la "clase media" o sociedad bourgeoise y liberal; no de la "economía moderna", sino de las economías y Estados en una región geográfica particular del mundo (parte de Europa y algunas regiones de Norteamérica), cuyo centro fueron los Estados rivales de Gran Bretaña y Francia. La transformación de 1789-1848 está constituida por el trastorno gemelo iniciado en ambos países y propagado en seguida al mundo entero. ${ }^{15}$

La concepción liberal del Estado y de la sociedad tiene también su correlato respecto a la pena, y por su propia dinámica abre necesariamente la discusión sobre ella misma, su fundamento y sus fines.

Un planteamiento clásico del Estado liberal burgués en relación a la pena lo constituye el de Kant: "Aun en el caso de que el Estado se disuelva voluntariamente, debe ser antes ejecutado el último asesino, a fin

12. Op. cit., p. 30 .

13. Gramsci, Antonio, «Antología», 1974, s. xxI, p. 316. Con mucha precisión señala Gramsci: «La revolución introducida por la clase burguesa en la concepción del derecho y, por tanto, en la función del Estado, consiste especialmente en la voluntad de conformismo (de aquí la eticidad del derecho y del Estado). Las clases dominantes anteriores eran esencialmente conservadoras en el sentido de que no tendian a elaborar una transición orgánica de İs demás clases a la suya, o sea, a ampliar "técnica" y ideológicamente su esfera de clase: su concepción era la de la casta cerrada. La clase burguesa se pone a sí misma como organismo en movimiento continuo capaz de absorber toda la sociedad, asimilándola a su nivel cultural y económico: toda la función del Estado se transforma...»

14. Como señala Poulantzas: «El Estado capitalista presenta de particular que el predominio propiamente político de clase no está presente en ninguna parte bajo la forma de una relación política clases dominantes-clases dominadas, en sus instituciones mismas. Todo ocurxe, en esas instituciones, como si fa "lucha" de clases no existiese.» (Poder Político..., p. 238).

15. Hobsbawm, Eric J.: «Las revoluciones burgutesas», vol. 1, 1974, Guadarrama, p. 16. 
de que su culpabilidad no caiga sobre el pueblo que no insistió en esta sanción: porque éste podría ser considerado copartícipe en esta lesión pública de la justicia», ${ }^{16}$ y en otro lugar agrega: «Las penas son, en un mundo regido por principios morales (por Dios), categóticamente necesarias (en tanto cuanto infracciones), pero en cuanto regido por hombres la necesidad de ellas es sólo hipotética, y aquella directa vinculación entre los conceptos de infracción y merecimiento de pena, sirve únicamente de justiffcación al Estado, pero no como compensación dentro de sus facultades.» $\gg^{17}$ En nada difere, por otra parte, el pensamiento de Hegel que se resume en su conocida frase de que la pena es la negación de la negación del Derecho. ${ }^{18}$ Es decir, la pena no puede ser ya expiación del pecado, pues se ha disuelto la unidad teligión-Estado, soberano-Dios, sino que es la retribución a la perturbación del orden (jurídico) que se han dado los hombres y consagrado por las leyes, la pena es la necesidad de testaurar el orden jurídico interrumpido. ${ }^{19} \mathrm{~A}$ la expiación sucede la retribución, la razón divina es reemplazada por la razón de Estado, la ley divina por la ley de los hombres. Se cae, pues, en el estricto positivismo legal..$^{20}$ En cierto modo se ha becho simpiemente una traspolación de lo divino a lo humano. Por eso mismo y también en tazón de formas ideológicas surgidas ya anteriormente en el mercantilismo, con su base de la libre relación económica entre los hombres, el fundamento de la pena no es otro que el libre albedrío: capacidad de decisión del hombre, de distinguir lo justo de lo injusto, falta de coacción sobre él para realizar el acto contratio a derecho. La teoría de la ficción de la autonomía envuelve necesariamente la teoría del libre albedrío.

El otro planteamiento clásico ba sido sustentado, entre otros, por Bentham, ${ }^{21}$ Schopenhauer ${ }^{22}$ y Feuerbach, ${ }^{23}$ esto es, la pena como prevención

16. «Metaphysik der Sitten», p. 331.

17. «Carta a J.B.F. Enhardt», Ed. de Meiner, p. 515.

18. «Grundinien der Philosophie des Rechts», $\$ 104$, en general véase $\$ 90$ y ss.

19. Sobre ello véase la concepción de Catrara, Francesco: Programa, $\$ 615, \$ 610$, $\S 614, \$ 619, \$ 612$.

20. Sobre el positivisno legal véase como ejemplo fundamental la obra de Binding, Kart: «Die Normen und ihre Ubertretungen», en especial sobre la pena, t. 1, 3a. ed., pp. 412 y ss. «Luego, la hístoria de la pena pública alemana sólo conoce un fin principal de ella: la conservación del señorío del derecho respecto del culpable según la medida de su culpabilidad.»

21. Véase sobre todo: «Théorie des peines et des técompenses.»

22. Sobre Schopenhauer véase Hoerster, Norbert: «Aktueiles in Arthur Schopenhauers Philosophie der Strafe», Archiv für Rechts-und Sozialphilosophie, 58, pp. 555 y ss.

23. «Lehtbuch des gemeinen in Deutschland gültigen peinilichen Rechts», 6a. ed. $\$ 8$ y ss. 
general. Se trata de prevenir en forma general los delitos, esto es, mediante una intimidación o coacción sicológica respecto de todos los ciuda. danos: «Este impulso sensual será eliminado en cuanto cada uno sepa que inevitablemente seguirá un mal a su becbo, que es mayor que el desagrado que surge del impulso no satisfecho bacia el becho. ${ }^{24}$ Esta teoría, como vemos, se debate entre dos ideas: la utilización del miedo ${ }^{25}$ y la valoración de la racionalidad del hombre. En el fondo esta teoría si no quiere caer en el totalitarismo total, en el terror, ${ }^{26}$ en la consideración del individuo como un animal que responde sólo a presiones negativas, tiene necesariamente que reconocer, por una parte, la capaciảad racional absolutamente libre del hombre, lo cual es una ficción al igual que el libre albedrío, y, por otra, un Estado absolutamente racional ${ }^{26 \text { bis }}$ en sus objetivos, lo que también es una ficción.

Tanto en una como en otra posición clásica se está ante teorías de transición entre el Estado absolutista y el Estado liberal. Esto lleva necesariamente a fundamentar la pena utilizando los planteamientos que los filósofos de la Ilustración opusieron al Absolutismo, esto es, de Derecho natural o de estricto laicisno: libre albedrío o miedo (racionalidad). En ambos en el fondo se sustituye el poder físico, el poder sobre los cuerpos, por el poder sobre el alma, sobre la siquis. ${ }^{27}$ Pero tales planteamientos críticos, por su época, tenían una taíz ficticia y mantenían concepciones autoritarias. A ello se debe la amplitud y aparente tolerancia por estas nuevas ideas de los Déspotas Ilustrados. Control mínimo, pero autoritario. «Los "Iluministas" que ban descubierto las libertades también han inventado la disciplina. $\$^{23}$ En todo caso, la prevención general se avenía más con el nuevo

24. Op. cit., $\$ 13$.

25. Cfr. Feuerbach, lug. cit.; cfr. Coddington: «Problems of Punishment», p. 343 y ss., en «Theories of Punishment», 1971, Indiana University Press.

26. Como señala Roxin: «...el punto de partida preventivogeneral tiene en ge. neral tendencia al terror estatal. Pues quien quiere intimidar mediante la pena, tenderá a reforzar este afecto castigando tan duramente como sea posible.) (Sentido y límites de la pena estatal), p. 18, en «Problemas Básicos del Derecho Penal», 1976, Reus, Madrid.

26 bis. Así, en la obra de Haffke, Bernhard («Tiefen Psychologie und Generalprävention», 1976, Sauerländer) aparece a cada momento ja voz «racional» en relación a las teorías de la prevención: «Cualquiera teoría de las sanciones del derecho criminal que se esfuerce por la racionalidad tiene que ser, por eso, en este sentido, una teoría de la prevención» (p. 59); «Como hemos resaltado anteriormente, las teorías de la prevención individual en general no difieren en el grado de su tacionalidad...» (p. 68), etc.

27. Cfr. Foucault, Michel: «Surveiller et Punir», 1975, Gallimard, pp. 21 y ss., en general pp. 9 y ss.; también Poulantzas: «Estado, poder...», pp. 28 y ss.

28. Foucault, op. cit., p. 224. 
Estado, ya que desprendía totalmente la pena de una consideración metasocial. Pero, evidentemente, todavía no se había llegado a una elaboración propia, a la estructura socio-económica del Estado burgués en desarrollo y que se condijera con su condición de Estado capitalista. En una primera época del Estado capitalista, como Estado liberal reducido a funciones de mera vigilancía, las teorías mencionadas podían aparecer como suficientes. Un desarrollo posterior de tal Estado capitalista hacía necesaria una readecuación de la concepción de la pena.

La industrialización acelerada, la utilización de la ciencia en el desarrollo de los medios de prođucción, el gran aumento de la población, la masiva emigración del campo a la ciudad, el fracaso de las revoluciones sociales de 1848, llevan a un claro asentamiento del modo de producción capitalista, cuya característica principal no es la posesión de un capital, sino la utilización de éste para la extracción de plusvalía de la fuetza de producción. ${ }^{29}$ A partir de aquí «la revolución industrial (británica) se había tragado a la tevolución política (francesa)m. ${ }^{30}$ Esta realidad es la que generalmente ha sido olvidada o encubierta por los juxistas, como destaca Miaille: «Si es verdad que el capital no es una suma de dinero, sino una relación social, esto significa que el Estado es inberente a esa relación social y no exterior: no se puede tratar al Estado como "alguna cosa" diferente y

29. Hobsbawm: «Lâ eta del capitalismo», wol $\downarrow$, pp. 15 y ss. Con mucha razón Dobb destaca dos rasgos especiales en el s. xIx: «El primero - y más conocido- es el hecho de que, en el s. xIx, el tempo del cambio ecenómico por lo que respecta a la estructura de la industria y de las relaciones sociales, al volumen de la producción y la amplitud y variedad del comercio, fue enteramente anormal, juzgando con el rasero de siglos anteriores: tan anotmal como para transformar radicalmente las ideas de los tombres acerca de la sociedad -a saber: de una concepción del mundo más - menos estática, según la que los hombres, de genetación en generación, estaban destinados a permanecer durante su vida en el puesto que les había sido asignado con el nacimiento, y en la que el apartamiento de la tatdición era algo contrario a la naturaleza, a una concepción del progreso como ley de la vida y del perfeccionamiento continuo como el estado normal de toda sociedad sana» (op. cit., p. 306)... «El segundo hecho es que el escenario económico del $s$. XIx $(0$, al menos, de sus primeras tres cuartas partes en Inglaterra) presenta una combinación de circunstancias excepcionalmente propicia para el favorecimiento de una sociedad capitalista. Período de cambio técnico, en él aumentó rápidamente ia productividad del trabajo; presenció también un incremento anormalmente pronunciado del número de proletarios junto con una serie de acontecimientos que ensancinaron simultaneamente el campo de inversiones y el mercado de consumo, en una escala sin precedentes» (p. 307). Y más atrás, para caractexizat el capitatismo había señalado: «... no bastia con que exista comercio o préstamo de dinero, $\circ$ una clase especializada de mercaderes o financistas -aunque sean hombres acaudalados- para constituir una sociedad capitalista. No basta que haya poseedores de capital, por "lucrativo" que sea: tienen que emplear ese capital para extraet plusvalía a la fuerza de trabajo en el ptoceso de producción» (p. 22).

30. Lobsbawm, E. J., «La exa...», vol. 1, p. 8; ifr. pp. 6 y ss. 
exterior al sistema capitalista. El es ese sistema. Es por eso que nuestra investigación no puede reducirse a una vuelta al juridicismo clásico. Nuestra hipótesis es que el Estado, a catsa de los juristas, siempre ba sido pensado como "más alla" del sistema social burgués; boy día es necesario comprender que él es ese sistema.»"

Las condiciones de explotación, de la que no escapaban ni las mujeres ni los niños, la miseria, el hambre y la desocupación, la violenta transfetencia del trabajador agrícola a la ciudad, significaron un peligro potencial para el thuevo orden existente..$^{32}$ Por otra parte, las aspiraciones sociales de los desposeídos que hasta la fecha sólo se habian manifestado espontáneamente por el apremio de sus necesidades, encontraban ahora, desde 1848 en adelante, un cauce político científico.

La pena no podía seguir siendo simplemente la restauración del orden juŕ́dico o la intimidación general de los ciudadanos, sino que tenía que ser en forma concreta y particular la defensa del muevo orden, por eso defensa social. Se trata de consolidar el nuevo orden, no sólo de establecer un control general como el de la retribución y el de la prevención general, sino de intervenir directamente sobre los individuos. El delito no es la contravención del orden jurídico, sino primero y antes que nada daño social, por ello defensa social, y el delincuente es un peligroso social (un anormal) que pone en peligro el nuevo orden. El delincuente es quien tiene la capacidad para el daño social, lo que es determinable científicamente, esto es, para los términos del siglo xIx, causalmente. ${ }^{33}$ La Revolución Francesa había roto el control del Estado absoluto, pero con ella no se había reconstituido un nuevo sistema de control definido para el nuevo Estado. El libre albedrío y el miedo o racionalidad no aparecían suficientes, más bien habían servido para combatir el sistema anterior y constituían por eso una ideología de transición. Ahora, con la teoría de la defensa

31. Op. cit. p. 20.

32. Como expresa Hobsbawn: «La historia de nuestro período es, pues, desproporcionada. Se compone primariamente del masivo avance de la economía mundial del capitalismo industrial, del orden social que representó, de las ideas y creencias que parecían legitimarla y ratificarla: en el razonamiento, ta ciencia, el progxeso y el liberalismo. Es la era de ia buxguesía triunfante, si bien la burguesía eutopea vacilaba aún en comprometerse con el gobierno político público. En este sentido, y quizá sólo en él, la era de la revolución no estaba muerta. Las clases medias de Europa estaban astustadas y siguieron estándolo, del pueblo: se pensaba todavia que la "democracia" era el seguro y rápido preludio del "socialismo",» ( «La era...», p. 8).

33. Para una sintética y acabada exposición del método positivista y sus deficiencias, véase Quinney, Richard: "Crime control in capitalist society: a critical philo. sophy of legal order», pp. 182 y ss., en «Critical Criminology», 1975, Rouledge and Kegan Paul. Sobre è positivismo en general véase Hobsbawm: «La eta...», vol, 2, pp. 122 y ss. 
social ${ }^{34}$ nace el Estado de control moderno como última instancia de resolución y participación directa en el control social de los disidentes. EI disidente no es el que rehúsa ser libre, cuestión teológica, o que no hace uso de su racionalidad o no es sensible al miedo, cuestiones sólo hipotéticas y no comprobables, sino que es el intrínsecamente perverso, un ser diferente a los otros, alguien que es necesario separar de la sociedad para ptotegetla. ${ }^{3 s}$ Su patología será biológica o social. Por ello, consecuentemente, se prefere hablar de medidas y no de penas. El positivismo naturalista o sociológico entrega nuevas armas ideológicas al Estado para la legitimación de su reacción sancionatoria frente al disidente. De ahí que ellas, por consiguiente, no se limiten sólo al caso de la comisión de deli. tos, sino que se tefieran al peligro social como $t a l l^{36}$ esto es, aun antes de cualquier acto normativamente demostrativo de tal capacidad. La teoría de la defensa social, con su expresión concreta en la teoría de la prevención especial, viene a cerrar el cicio de una evolución y a representar en forma definitiva al Estado capitalista. Pero, como muy bien se pregunta Roxin: «¿Qué legitima que Ia mayoría de una población obligue a la minoría a acomodarse a las formas de vida grata de aquéllas? ¿De dónde obtenemos el derecho de poder educar y someter a tratamiento contra su voluntad a personas adultas? ¿Por qué no han de poder vivir los que lo hacen al margen de la sociedad -bien se piense en mendigos o prostitutas, bien en homosexuales- del modo que deseen? La circunstancia de que son incómodos o molestos para muchos de sus conciudadanos, ces causa sufi" ciente para proceder contra ellos con penas discriminantes? ${ }^{37}$ Ciertamente el Estado liberal, al oponerse al Estado absolutista, puso en el tapete de la discusión la cuestión de la legitimidad del Estado, pero en caso alguno la solucionó. Los problemas de legitimidad en el Estado capitalista residen siempre en la imposibilidad de dar una explicación satisfactoria tanto de la explotación del trabajador como de su sistema de control tepresivo, esto es, de someter, disciplinar o hacer dóciles a los individuos respecto a dicho sistema de explotación del trabajador.

De una u otra manera, durante gran parte del siglo $\mathrm{xx}$ han coexistido las dos posiciones fundamentales en torno a la pena. La mayor o menor

34. Sobre los inicios y más destacada consolidación de la teoría de la defensa social, véase Ferri, Enrique: «Principios de derecho criminal», 1933, Madtid, p. 194 y ss., p. 225, p. 266.

35. Sobre ello ver sobre todo el punto de vista biológico-antropológico de César Lombroso: «L'uomo delinquente.»

36. Cfr. Dobb, op. cit., pp. 326 y ss.; también expresión de elto es la Ley de Vagos y Maleantes de 1933 en España.

37. Roxin, op, cit., p. 17. 
preponderancia de una u otra concepción ha respondido también a los diferentes matices de las formas asumidas por el Estado capitalista. En aquellas sociedades altamente jerarquizadas y en que ha perdurado la forma ideológica del Estado-autoridad (que llegaron más tarde al Estado liberal), como es el caso de Alemania, han tenido mayor éxito el tetribucionismo o la prevención general; en aquéllas, en cambio, en que el Estado aparece más claramente como «la voluntad soberana del pueblo», caso de Estados Unidos, países nórdicos, Francia, etc., ha tenido mayor relevancia el positivismo naturalista o sociológico.

Pero el Estado burgués ha continuado en su desartollo, ${ }^{37}$ bis ha pasado al nivel de los grandes monopolios, de las empresas transnacionales, del imperialismo, todo lo cual ha obligado al Estado a intervenit, justamente para mantener la relación capital-trabajo, que puede peligrat sin su mediación; de ahí su actuación en una gran cantidad de esferas: educación, salud, investigación, etc., y en tal medida se ha hecho también más patente su control social. Como muy bien señala Jürgen Habermas, «con las fallas de funcionamiento del mercado y los efectos secundarios disfuncionales de este mecanismo de regulación entra también en quiebra la ideología base burguesa del intercambio equitativo. Por otra parte, surge con más fuetza la necesidad de legitimación: el aparato del Estado, que ahora ya no sólo asegura los presupuestos de existencia del proceso de producción, sino que introduce en él iniciativas, tiene que ser legitimado en el creciente ámbito de la intervención estatal». ${ }^{38}$

El planteamiento del contrato social ha sido ampliamente sobrepasado, la democracia neoliberal necesita además del consenso efectivo para mantener incólume la relación capital-trabajo. Como señala un funcionalista, N. Luhman: "Visto políticamente se comprueba que poder "absoluto" se convierte en una ficción, porque el poder sólo puede set construido en procesos de comunicación motivados recíprocamente, en referencia al intercambio; quien quiere ganar poder debe abrirse a la infuencia. La tentativa de estabilizar el sistema parcial político de la sociedad como dominio absoluto exclusivamente mediante programas de objetivo fracasó con el Estado policial.» ${ }^{39}$ El Estado tiene que intervenir para logtar estos procesos de comunicación, para lograr esta relación de consenso, condiciones necesarias para la subsistencia de las relaciones capital y trabajo, condiciones necesarias para su propio poder. En tal sentido, la pena resulta inadecuada

37 bis. Cfr, Miliband, Ralph: «El Estado en la sociedad capitalista», 1978, s. XxI, véase en especial pp. 13 y ss. $(15,16,18)$. p. 308 .

38. «Zur Rekonstruktion des historischen Materialismus», 1976, Suhrkamp,

39. «Zweckbegriff und Systemrationalität», 1973, Suhrkamp, p. 105. 
como simple retribución o prevención general, como simple guardiana del orden, lo que aparece como más propio para una concepción liberal primitiva. Resurge, pues, con toda su fuerza, aun en Alemania, la defensa social, pero lógicamente replanteada, no como en la época positivista del nacimiento de la sociedad industrial. La Primera y la Segunda Guerra Mundial y sobre todo las crisis entre ellas remodelaron tales concepciones; el funcionalismo da el marco teórici a la ideología del orden y del consenso, al equilibrio social. Tales planteamientos, y el antecedente del funcionalismo, se encuentran ya en uno de los llamados padtes de la sociología, Émile Durkheim, con su conocido concepto de la conciencia colectiva, esto es, «el conjunto de creencias y de sentimientos comunes a la media de los miembros de una misma sociedad, forma un sistema determinado que tiene su vida propia... ${ }^{40}$ De aguí parte toda la teoría de la anomia y de la conducta desviada, que es recogida por los funcionalistas americanos, Talcott Parsons y en especial Merton. ${ }^{11}$ Lo que interesa, por una parte, es analizar las condiciones que hacen posible el ataque a los supuestos del consenso y, por otra, analizar las condiciones que hacen posible la reinserción o reeducación del individuo (esto es, de sujetarlo a esos supuestos). Por eso el control alcanza a todo disidente social, económico, político. La minoría autónoma no tiene lugar, sólo la minoría sometida dentro del organismo total. Pero, a su vez, la mayoria se logra mediante una serie de mecanismos de dominación-subordinación, entre los cuales también tienen importancia fundamental los de encubrimiento de la dominación y los de coacción de los subordinados. El consenso logra una mecánica de constante reproducción de la mayoría e inserción de la minoría o de su eliminación. ${ }^{42}$

Este proceso es el que ha hecho caer en crisis sobre todo a la prisión como medio de ejecución de la pena, pues no sirve para los fines reseñados anteriormente (salvo el extremo de eliminación), sino todo lo contrario, ya que sepata al individuo de la sociedad, lo deja fuera de todas las motivaciones del consenso. Los últimos restos del Estado absoluto - autoridad han quedado sobrepasados por el desarrollo socio-económico. La pena queda en definitiva entregada a la racionalidad del consenso, ella es su base y su justificación. El movimiento defensista que había perdutado en Italia y países nórdicos, renovado, se extiende ahora por todas partes, cuando el

40. «De la division du travail social», 1967, p. 46, P.U.F., 8a. ed.

41. Talcott Parsons: «Sistemi di società», II, 1973, il Mulino, pp, 22 y ss.; "Voting" and the equilibrium of the American Political System», en eAmerican Political Behaviour», 1959, p. 101; Merton, Robert, K.: «Teoría y estructuras sociales», 1964, pp. 131 y ss.

42. Cfr. Poulantzas: «Estado, Poder...», pp. 172 y ss.; «Poder politico...», pp. 242 y 269; Miliband: op. cit., pp. 47 y 71. 
desarrollo socio-económico hace más evidente la correspondencia entre el Estado surgido de ese desarrollo económico y sus funciones, dentro de las cuales está, evidentemente, Ia del control social de los disidentes. No es extraño entonces que en la Constitución Española, art. 25, núm. 2, se exprese: «Las penas privativas de libertad y las medidas de seguridad estarán orientadas bacia la reeducación y reinserción social...» Así también el P. A. 66 alemán establece en el parágrafo 2: "Las penas y medidas de seguridad sirven para la protección de los bienes jurídicos y la reintegtación del autor en la comunidad jurídica.»

No se puede negar, y sería erróneo plantearlo así, que no ba habido objetivamente un progreso. El abandonar la pena expiatoria o tetributiva ha implicado un avance en la conciencia de la realidad socio-económica misma y de la posición del individuo. Así como se ha desmitificado el Estado se ha desmitificado la pena, se ha abierto el camino a la constante rediscusión y crítica. Evidentemente la casa de trabajo o la cárcel constituyó un avance en relación a los castigos corporales. También es un avance que la pena no se funde ni mida desde el libre albedtío, miedo o una racionalidad absoluta, ya que se trata de categorías sin realidad alguna o a lo más de metáforas; en ese sentido también és un avance significativo tomar conciencia de todos los fallos que aquejan a las penas en particular y en especial a la de prisión. También es importante poner el acento en los bienes jurídicos y en la resocialización del delincuente. No se puede negar que todo ello constituye un avance histórico social, no se trata de volver attás, como pretenden algunos.

Pero la cuestión de fondo continúa subsistiendo, esto es, estamos ante una sociedad en la que si bien cada vez con mayor nitidez se ha desplazado la dependencia personal, en cambio cada vez más se acentúa la dependencia de las cosas; mantenimiento de la sociedad de consumo, de la relación capital-trabajo. Ahora bien, el consenso a obtener es respecto de esta dependencia; ella es elevada a razón de Estado, el Estado tiene por función lograr su mantenimiento. Desde tal punto de vista, el individuo aparece de partida sometido a tal consenso y producto de él, la pena no cumple otro fin que resometer (el bien jurídico no es sino expresión de una determinada pauta de relación social, la pena tiene por objeto resometer al individuo a esa pauta), en eso consiste en definitiva la resocialización, y respecto del disidente de cualquier naturaleza. El hombre pasa a ser un simple instrumento manipulable en relación a su dependencia de las cosas, la pena es una forma de manipulación. ${ }^{43}$ Así el paro, como fenómeno

43. Cfr. Muñoz Conde, Francisco: «E1 principio de culpabilidad», pp. 232 y ss., en «III Jornadas de Profesores de Derecho Penal», Universidad de Santiago de Com- 
necesario dentro del esquema económico-social, provoca una gran cantidad de disidencias, hasta la más extrema que es la delictiva; sin embargo, éstas no son aceptadas ni asumidas por el Estado, que justamente obliga a considerar el paro como algo necesario, y la pena como resocialización sólo puede tener como fin, en este caso concreto, obligar al individuo a aceptar tal condición suya de desvalimiento y de sumisión a las cosas. Aquí está, pues, el punto más crítico de una pena resocializadora, ${ }^{44}$ resocialización a qué sociedad y para qué. Resulta, por tanto, ineludible intentar una breve incursión sobre el carácter del Estado o su problemática en el capitalismo actual (llamado también postcapitalismo). Así, para Ralph Miliband el Estado se convierte en un instrumento de la clase capitalista (teoría intrumentalista), esto es, el Estado sirve a los intereses de la clase capitalista porque ella es la que lo controla. Tal posición de Miliband aparece claramente expresada en los siguientes párrafos: «Según el esquema marxista, "la clase imperante" de la sociedad capitalista es la que posee y controla los medios de producción y, en virtud del poder económico de tal manera detentado, puede utilizar al Estado como instrumento para el dominio de la sociedad.... ${ }^{45}$ «No obstante, el capitalismo avanzado es prácticamente sinónimo de empresa gigantesca; y nada de la organización económica de estos países tiene más importancia fundamental que el creciente dominio de sectores claves de su vida industrial financiera y comercial por un número relativamente pequeño de empresas gigantescas fuertemente conectadas...»" «Lo que tiene de malo la teoría democrático-pluralista no es su insistencia en el hecho de la competencia, sino su afrmación (y muy a menudo su presupuesto implícito) de que los principales "intereses" organizados de estas sociedades, y sobre todo el capital y los trabajadores, compiten en términos más o menos iguales, y, por consiguiente, ninguno de ellos es capaz de alcanzar una ventaja decisiva y permanente en la com. petencia. Es aquí donde aparece la ideología y la observación se convierte en mito. En capítulos anteriores se mostró que el mundo de los negocios

postela. Sobre este aspecto, ađemás, en general, véase la completa monografía de Quintero Olivares, Gonzalo: «Represión Penal y Estado de Derecho», 1976, Dirosa. Como muy bien destaca el autor: «Esta conexión entre lo penal y lo político no se reduce a una vinculación entre la ley positiva y la ideología dominante, aun cuando ello sea el dato inmediatamente aprehensible, sino que debe alcanzar, y de hecho asi sucede, a la explicación o crítica científica de los preceptos positivos o de las convicciones dominantes» (p. 22).

44. Sobre los problemas de la Readaptación social, véase la completa monografía de Bergalli, Roberto: "¿Readaptación social por medio de la ejecución penal?", 1976, Instituto de Criminología de la Universidad de Madrid.

45. Op. cit, p. 24 .

46. Op. cit., p. 13; cfr. también p. 15. 
y en particular las empresas en gran escala, disfrutan de tal ventaja dentro del sistema estatal, en virtud de la composición y de las inclinaciones ideológicas de la élite estatal. En este capítulo veremos que el mundo de los negocios disfruta de una formidable superioridad también fuera del sistema estatal, en términos de las presiones inmensamente más fuertes que, por comparación con los trabajadores y con ottos intereses, puede ejercer en la consecusión de sus fines. $\rangle^{47}$

Para otros autores, como es el caso de Poulantzas, lo fundamental no es el carácter instrumentalista del Estado, sino analizar cómo se expresan y se dan las relaciones del Estado con las estructuras de la sociedad, en la cual adquieren una importancia fundamental las relaciones de producción (teoría estructuralista). Es así como Poulantzas señala: «Lo que nos lleva a una conclusión simple, pero que nunca se repetirá bastante. Esa garantía de intereses económicos de ciertas clases dominadas por parte del Estado capitalista no puede concebirse sin más como limitación del poder politico de las clases dominantes. Es cierto que se le impone al Estado la lucba política y económica de las clases dominados: esto, sin embargo, significa simplemente que el Estado no es instrumento de clase, que es el Estado de una sociedad dividida en clases... ${ }^{48}$ "Resumo: si son las relaciones de producción (tales o cuales) las que configuran el campo del Estado, éste tiene sin exbargo un papel propio en la constitución misma de esas relaciones. La telación del Estado con las relaciones de producción es una primera relación del Estado con las clases sociales, con la lucha de clases. En lo concerniente al Estado capitalista, su separación relativa de las relaciones de producción instauradas por éstas es el fundamento de su armazón organizativa y configura ya su relación con las relaciones sociales y la lucha de clases bajo el capitalismo. ${ }^{49}$

Otros autores, entre los cuales está Claus Offe, discipulo de Habermas, critican tanto a los instrumentalistas como a los estructuralistas, en razón de que ni unos ni otros hacen un análisis de aquellos mecanismos propios al Estado, que justamente plantean su carácter de clase: «Esta contribución investiga algunos problemas analíticos y metódicos, que van unidos al intento de una teoría marxista del Estado. Punto de partida es el problema del carácter de clase del Estado, o más exactamente: la resolución de la inconsistencia por lo menos aparente de que el Estado, aunque no es él mismo capitalista, sin embargo tiene que ser comprendido

47. Op. cit., p. 141 .

48. Cfr. Poulantzas: «Poder político...» p. 242; cfr. también: «Estado, poder...», pp. $6 \mathrm{y} \mathrm{s}$.

49. "Estado, Poder...", p. 24. En relación a la Ilamada «autonomía relativa de este tipo de Estado», cfr. «Poder político...», pp. 332 y ss. 
como Estado capitalista - y no sólo como "Estado en la sociedad capitalista". ${ }^{50}$ Para la dilucidación de esta problemática Offe concibe el dominio estatalmente organizado como un "proceso de selección» y en que por lo tanto de lo que se trata es de averiguar «¿qué rendimientos de selección especificos tiene que practicar un aparato de Estado para oficiar como Estado capitalista? $\gg^{51}$ Son estos procesos los que estudia Offe, señalando aquellos que consisten en excluir de la actividad estatal a los intereses anticapitalistas, en favorecer aquéllos referidos a los intereses del capital en su conjunto y no aquéllos mezquinos de interés particular capitalista, en encubrir con una apariencia de neutralidad de clase las instituciones del Estado. Pero en todo caso, para Offe, a pesar de este análisis teórico, cuando estos procesos de selección funcionan eficazmente resulta empíricamente imposible demostrar el carácter de clase del Estado; éste sólo aparece en momentos de crisis: "El carácter de clase del Estado se evidencia post festum, esto es, cuando en los conflictos de clases - y sólo con ello también para el conocimiento objetivado- aparecen las fronteras de sus ${\text { funciones. })^{52}}^{52}$

De una u otra manera, en mayor o menor medida, Antonio Gramsci ha servido de fuente a todos estos estudios del Estado capitalista, con su conocida distinción entre sociedad civil y sociedad política a efectos metodológicos. Sociedad civil «en el sentido de hegemonía política y cultural de un grupo social sobre la entera sociedad como contenido ético del Estadon, ${ }^{53}$ y sociedad política en el sentido del aparato de gobieno, del aparato coactivo y dictatorial. Es por eso que para Gramsci no hay una oposición entre Estado y sociedad, sino que el Estado es «sociedad política + sociedad civil, o sea, como hegemonf́a acorazada con coacción». ${ }^{54}$

También desde un punto de vista estrictamente liberal se realizan análisis sobre el carácter del Estado. Es el caso de Robert Nozíck: «Nuestras conclusiones principales sobre el Estado son de que un Estado mínimo, limitado a las exiguas funciones de protección en contra de la fuetza, robo, fraude, coacción contractual, y asî sucesivamente, está justificado; de que cualquier otro Estado más extensivo violará los derechos de la petsona a no ser forzada a hacer ciertas cosas, y es injustificado... Dos implicaciones notables son que el Estado no ha de usar su aparato coercitivo para el propósito de lograr que algunos ciudadanos ayuden a otros o en orden

50. «Strukturproblem des kapitalistischen Staates», 1972, Suhrkamp, pp. 65 y 66.

51. Op. cit., p. 74 .

52. Op. cit., p. 90 .

53. Op. cit., p. 290.

54. Op. cit., p. 291. 
a prohibir actividades a la gente para su bien o protección propios. $\rangle^{55}$ Para Nozick ese Estado mínimo es necesario y legítimo (para lo cual hace un análisis de la teoría del Estado natuxal, cuya evolución necesaria y legítima tiene que terminar en el Estado mínimo), por tanto superador de cualquier posición anárquica y a su vez esqueleto de cualquier utopía.

De todo lo anterior aparece claro que el Estado no puede ser considerado como agotado en su carácter de instrumento de dominación de una clase. Es necesario llevar a cabo un análisis de las estructuras mismas que componen el Estado; sólo a través de ellas podrá lograrse una comprensión más global del Estado. Pero también es cierto que para tai efecto no basta con el análisis de las estructuras, sino que al mismo tiempo es indispensable analizar cómo funciona el Estado; hay, pues, un proceso dialéctico de estructura a funciones y de funciones a estructura. Por ello, para tal análisis resulta sumamente aclaratoria la división metodológica entre sociedad civil y sociedad política dentro del Estado. Frente a todo esto, al planteamiento de Nozick se le puede aplicar la frase de Offe: «Desde la perspectiva de pájaro de los teóricos de sistema, como desde la perspectiva de sapo de los behavioristas, todos los gatos son igualmente grises. ${ }^{56}$ Realmente la obra de Nozick, desde las alturas, está plagada de buenas intenciones, pero totalmente desconectada de la realidad, ni siquiera utópica -meta para una revolución-, sino simplemente imaginaria. El problema parecería no estar en demostrar la necesidad abstracta y absoluta de Estado, to que es indemostrable, sino de analizar una forma determinada de Estado y en este caso la del Estado capitalista actual. Por otra parte, no se trata de plantear una concentración de una determinada forma de Estado, que entonces continúa siempre siendo tal y, más aún, acentúa su carácter de clase.

El aspecto más importante dentro del Estado capitalista reside en su constante contradicción interna desde sus orígenes, pues si bien por una parte pretende representar a todos, cumplir las aspiraciones de todos, por otra, como Estado de una sociedad de clases, hay un grupo que establece su hegemonía y dicha apariencia de totalidad no puede destruir los inteseses de ese grupo económico; pero a su vez éste, para subsistir, para lo cual es necesaria la subsistencia de ese Estado, necesita ir respondiendo de algún modo a las aspiraciones de las demás clases. En ello reside también la gran vitalidad del Estado capitalista, pues necesariamente tiene que ser un sistema abierto y flexible, tiene que irse reproduciendo y acrecentando, de abí su carácter democrático, que, aunque sea imperfecto,

55. "Anarchy, State and Utopia», 1974, Basil Blackwell, p. IX.

56. Op. cit., p. 84 . 
origina una democracia. Sus crisis están constituidas por aquellos momentos en que no se encuentran los mecanismos para conformar a los demás dentro de los intereses del grupo hegemónico, y es en esos casos cuando se tiende a cerrar el sistema y surge el nazismo, fascismo, bonapartismo, dictaduras militares latinoamericanas, otras formas de autoritarismo y, últimamente, la doctrina de la seguridad nacional." Este cierre del sistema puede llevar a la eliminación de la democracia o a una democracia vigilada ${ }^{58}$ Otro camino, en cambio, es el de no cerrar el sistema e irlo abriendo constantemente, esto es, que se produzca una identidad democrática entre sociedad política y sociedad civil, que el Estado sea realmente de todos y realmente resida en la sociedad toda, que ei Estado se identiffque democráticamente consigo mismo, y ése será el momento de su desaparición.

De todos modos, los autores anteriormente citados, también Nozick, coinciden en un punto, esto es, que en el Estako actual se recogen o se generan desigualdades, y que por tanto es necesatia una modificación del mismo. Todos ellos a su vez teconocen en el Estado su función represiva, más aún, el Estado como ejerciendo el monopolio de ta violencia legítima. ${ }^{59}$ Pero la cuestión es justamente si a ese Estado que en gran medida es productor de sus delitos y delincuentes ( «También en este campo es el Estado un instrumento de "racionalización", de aceleración y de taylorismo, obra según un plan, ptesiona, incita, solicita y "castiga", puesto que, una vez creadas las condiciones en las cuales es "posible" un determinado modo de vida, la "acción u omisión criminales" han de tener una sanción punitiva de alcance moral... $)^{\infty}$ se le puede reconocer la potestad de resocializar mediante la pena. Ello sería desconocer sus fallos estructurales, sus relaciones de dominación-subordinación, plantearse abora la existencia de una sociedad utópica o en último estadio de su desarrollo, to cual todavía no hemos alcanzado. Al Estado actual sólo se le puede reconocer,

57. Sobre el problema de capitalismo y represión en la actualidad véase el libro de Accattatis, Vicenzo: «Capitalismo e Repressiones, 1977, Feitrinelli, en especial pp. 98 y ss. Como muy bien ha señalado Miliband: «Que el capitalismo es incompatible con el autoritarismo, o que constituye una garantía de protección contra el autoritarismo, podrá ser buena propaganda, pero muy triste sociołogía política.) (Op. cit., p. 22).

58. Dentro de estas estrafalarias combinaciones es rtuy representativa la siguiente frase de Pinochet: «Esta lucha que tenemos es de los cue no somos comunistas, de los que amamos la libertad y comprendemos que hoy díi es necesario vivir en democracia, aunque el gobierno sea autoritario. (Frase cit. revista "Hoy», núm. 101, p. 4).

59. Cfr. R. Nozick: op. cit., p. 23, pp. 54 y ss.; Poulantzas: «Estado, Poder...», pp. 28 y ss., pp. 87 y ss. (94); Miliband, op. cit., pp. 52-54; Gramsci, op. cit., p. 400.

60. Gramsci: op. cit., p. 400. Cfr. tambien Plack, Arno: «Die Gesellschaft und das Böse», 1974, Paul List Venlag, p. 119. 
con razón, la potestad para democratizar y socializar la pena. Esto es, ir, por ejemplo, a la progresiva eliminación de la pena de prisión y en todo caso a su transformación en un sistema democrático y no jerarquizado; en general, que la pena tenga por sentido ofrecer al individuo todas aquellas oportunidades que le fueron negadas (enseñanza, salud, profesión, etc.). Esto aparece más evidente si se considera que en general el que llega a la cárcel es el disidente del sistema y no el que se aprovecha de él. Si la pena es expresión de la violencia del Estado, si necesariamente como tal expresión de violencia ha de constituir un mal, no se puede dejar de estar de acuerdo con Nozick en el sentido de que debe ser un mínimo (idealmente expresión de un Estado mínimo) — cualquier exceso convierte al Estado en un Estado de terror-, exceso que es propio a las crisis del Estado capitalista, cuando se suprime o se vigila la democracia.

\section{PENA Y ESTADO DEMOCRATICO}

Cuando hablamos de Estado democrático nos estamos refitiendo a todo aquel que no aparece exclusivamente reducido a su aspecto coactivo puro, sino que por ello mismo aparece como un sistema abierto y en constante proceso de apertura. No a una democracia total y perfecta, aún utópica.

De lo que se trata ahora es, pues, de determinar con precisión lá problenática de la pena en un Estado democrático.

Para ello, en primer lugar, es necesario examinar qué es la pena (problema generalmente olvidado, confundido con una definición formal, como es el caso de H. L. A. Hart), ${ }^{61}$ tratando de eliminar todas las mixtificaciones que han surgido en torno a ella. Podría decirse que la pena es expiación, es decir, el simple establecimiento de mal por mal. Peto si esto puede traducirse en la frase «ojo por ojo, diente por diente», carece de sentido en la apreciación de los males. No siempre, mejor dicho nunca, se trata de un ojo por ojo. Esta pretendida fundamentación y medición de los males sólo es una metáfora. "La teoría de la expiación no nos puede servir, porque deja sin aclarar los presupuestos de la punibilidad, porque no están comprobados sus fundamentos y porque, como conocimiento de fe irracional y además impugnable, no es vinculante. $\rangle^{2}$ Tal pena es propia de los

61. Hart, H.L.A.: «Prolegomenon to the Principles of Punishment», p. 357, en «Theories of Punishment». Esta definición ta recoge Koller, Peter: «Probleme der utilitaristischen Strafrechtfertigung», p. 45, en ZStW. 91.

62. Roxin, op. cit., pp. 14-15. Cfr. también al respecto Hoerster, Norbert: «Die philosophische Rechtfertigung staatichen Strafens», p. 372, en ZphF 28. 
Estados absolutos en que hay identidad entre Dios y soberano y Estado, y por ello se cree itracionalmente en la capacidad absoluta para determinar y medir males.

Podría pensarse que la pena es retribución. Nos situamos en los albotes del capitalismo y por eso la vigencia de este planteamiento hasta la actualidad, siendo acogido por los más diferentes autores: Kant, Hegel, Carrara, Welzel, etc. Se trata del restablecimiento del otden jurídico, de una necesidad social de mantención del orden. Como dice Jackson Toby, lo que recuerda mucho a Catrata, todo (rehabilitación, tratamiento, reincidencia, etc.) «tiene menos importancia que la neutralización del desviado como modelo de rol posibles. ${ }^{6}$ Pero e!lo es una ficción igual a la de la teoría de la expiación; la fe irracional en el orden metasocial se convierte en fe irracional en el orden social. ¿Cómo se concreta, adernás, esta idealidad y se condensa en la pena? ${ }^{63}$ bis ¿Qué es la ruptura del orden y su restablecimiento pos la pena? Detrás de todo esto hay una concepción autoritaria del Estado y por eso una pena autoritaria. Pot otra parte, esta teoría en la actualidad, como señala Haffke, tiende a trasvasarse hacia la prevención general, luego hacia una concepción telativa de la pena, esto es, que la imposición del mal de la pena «reforzará la fidelidad al derecho de la generalidads ${ }^{64}$ Se navega entse dos aguas: retribucionismo y prevención general. . $^{\text {s }}$

Podría pensarse que la pena es prevención general, es decir, que la pena no se agota en sí misma como mal, sino que tiene una finalidad externa: la conminación sobre la generalidad para evitar que cometa delitos. Tanto la teoría de la prevención general, como la de la prevención especial, no contestan directamente lo que es la pena, ya que se preocupan más bien por los fines de la pena. En realidad, tanto una como otra tratan de obviar esta problemática y partir, entonces, de un Estado neutral y una pena neutral, esto es, que beneficie a todos, sin contradicciones internas, y allí estaría su justificación. Es una consecuente aplicación de la teoría del Estado liberal. Así, por ejemplo, B. Haffke expresa: «La prevención general es un instrumento de control social y como tal neutro valorativamen. te. $1^{66}$ En principio, queda además sin contestat la objeción planteada por

63. «Is Punishment Necessary?», p. 112, en «Theories of Punishment», cit. 63 bis. Cfr. Hoerster, Norbert: op. cit., pp. 372 y ss.

64. Op. cit, p. 77.

65. Lo mismo sucede con algunos autores cuando tratan de analizar la culpabilidad desde un punto de vista preventivo general, que también llegan a planteamientos retributivos, en el sentido de mantenimiento del ordenamiento. Así por ejemplo, Jakobs, «Schuld und Prävention», pp. 10 y 24.

66. Op. cit., p. 86 (cfr, también p. 83). 
Roxin: "Queda sin resolver frente a qué comportamientos tiene el Estado la facultad de intimidar; la doctrina de la prevención general comparte con las teorías de la retribución y de la corrección este punto débil, a saber, que queda $\sin$ aclarat el ámbito de lo punible. $\aleph^{67}$ Tampoco se responde a la antigua crítica de Kant de que el individuo no debe set utilizado como medio para las intenciones de otro ni quedat incluido dentro del Derecho de cosas. Estas críticas han intentado ser objetadas por diferentes autores. Así, Hoerster señala: «La objeción kantiana de que no se debe degradar al individuo a un medio de medidas de utilidad social sólo sería contundente si la medida respectiva apareciese respecto del individuo atbitraria e injusta. $\rangle^{6}$ Por eso, para Hoerster «la justificación buscada del castigar estatal reside, conforme a todo lo anterior, en la combinación de los puntos de vista de la prevención general y de la distribución justa: que el Estado castigue está justificado por la prevención general. Cómo él castiga (esto es, a quién y en qué medida castiga) es un problema de la distribución justa». ${ }^{69}$ En términos parecidos se expresan Koller ${ }^{70}$ y Haffke. ${ }^{71}$ De todos modos, queda sin aclarar por qué se pena, ya que el argumento de prevención general no es suficiente. Estos autores simplemente trasladan el problexa desde la prevención general a una argumentación sobte la justicia en particular, basada en la racionalidad, distribución equitativa o justa o igualitaria o socialmente ética por parte del Estado. ¿Pero existe tealmente esa razón de Estado o social que nos permita demostrar tal distribución justa o racional? Estos planteamientos aparecen puestos en duda con mucha claridad por parte de Nozick: "¿Pero por qué no ptzede violarse a las personas por el bien social superior?... ¿Por qué no sostener, en forma similar, que algunas personas tienen que soportar algunos costos que beneficien a más personas en razón del bien social general? Peto no hay entidad social con bienes que soporte algún sacrificio por su propio bien. S6lo hay gente individual, diferente gente individual, con sus propias vidas individuales. Usando una de esas gentes en ei beneficio de otras, se la usa a ella y se beneficia a los otros. Nada más. Lo que sucede es que se le hace algo a ella en razón de otros. Hablar de un bien social general encubre esto. (¿Intencionalmente?) El usat a una persona de esta manera no es respetar suficientemente y tener en cuenta el hecho de que es una persona separada, que la suya es la única vida que tiene. $\rangle^{72}$ Con esto real-

67. Op. cit. p. 18.

68. Op. cit., p. 376.

69. Op. cit., p. 377.

70. Op. cit., cfr. p. 53.

71. Op. cit., cfr. p. 83; cfr. también Hart, H.L.A.: op. cit., pp. 361 y ss.

72. Op. cit. pp. 32-33 (último subrayado nuestro). Cfr. también Coddington 
mente se toca a fondo la argumentación dada por los partidarios de la prevención general, en lo que se refiere a su fundamentación, desde un punto de vista estrictamente liberal. Pero no sólo desde el punto de vista liberal estricto aparece criticable esta posición, sino también desde un punto de vista democtático en general. ¿Es realmente posible en el Estado actual hablar de una distribución racional o igualitaria en lo particular? En caso alguno. La sola lectura de la breve exposición sobre el Estado actual al finalizar el capítulo anterior, señala lo peregrino de una tal afirmación. Ni la racionalidad ni la distribución igualitaria son virtades inherentes o inmanentes al sistema: están subordinadas a los intereses concretos de un grupo hegemónico. Es por eso que hemos dicho que la teoría de la prevención general o cae en la utilización del miedo como forma de control social, con lo cual en el Estado de terror y en la transformación de los individuos en animales, ${ }^{73}$ o bien en la suposición de una tacionalidad absoluta del hombre en el sopesamiento de bienes y males, en su capacidad de motivación, lo cual es una ficción como el libre albedrío, y, por último, se cae en la teoría del bien social o la utilidad pública, que lo único que hace es encubrir la realidad de los intereses en juego, de una determinada socialización y, en definitiva, los fallos, contradicciones y conflictos de una democracia todavía imperfecta. Es por eso que quienes se dan cuenta de esto llegan a posiciones integrativas, ${ }^{74}$ muy bien sintetizadas en su difusidad por Haffke: «Aspiramos a un control social jurídico-penal racionai y esclarecido, que cuente con las debilidades-del-yo y sin embargo lo trate humanamente... Un Derecho penal preventivo general concebido de esta manera es en el mejor sentido Derecho evolutivo-progresivo, que aspira a producir condiciones sociales más libres --condiciones en las cuales ojalá algún día la pena intimidatoria no aparecerá más como necesaria. ${ }^{75}$ Pero esto no deja de ser una ilusión y no una utopía, a pesar de lo que expresa Haffke, pues no se puede liberar mediante ficciones, subyugación

op. cit., pp. 339 y ss., quien señala: «ciertamente la protección del público es un buen eslógan, ....pero no pienso que apunte exactamente al propósito social ideal del castigon (p. 340).

73. Así señala muy pragmáticamente, por ejemjlo, Coddington: «El miedo, aun cuando tenga efecto, no es un motivo ennoblecedot, y una persona que se abstiene del crimen exclusivamente porque teme las consecuencias, es espiritualmente muy inferior, y también como capital social, respecto de quien se comporta bien porque quiere ser un sujeto decente..., (p. 345).

74. Cfr. Haffke, op. cit., pp. 162 y ss.; Koller, op. cit., pp. 82 y ss.; Coddington, op. cit., pp. 352 y s., etc.

75. Op. cit., p. 166. Cfr. la nota 14 de esta página en que Haffke plantea que lo que sostiene no es la ilusión de una sociedad libre de criminalidad sino una utopía concreta en que la necesidad del control social jurídicopenal no exista más. 
y cosificación de la persona humana, ni con el encubrimiento de los procesos reales que se dan en la sociedad. ${ }^{76}$

Podría pensarse que la pena es prevención especial, esto es, que implica un tratamiento respecto del individuo en particular. No se trata, pues, de prevenir a la genetalidad, sino de prevenir respecto del individuo en particular en cuanto a futuras recaídas en el delito. A esta teoría se le pueden plantear las mismas objeciones generales en cuanto a su legitimidad que se han examinado respecto de la teoría de la prevención general. Pero, además, es necesario considerar que la teoría de la prevención especial parte de la consideración del delincuente como un ser peligroso socialmente. El problema está en determinar entonces qué es peligroso y quién determina lo que es peligroso, lo cual generalmente constituirá una sola problenática. Con más claridad aún que en la teoría de la prevención general, tesulta que es peligroso aquello que un grupo hegemónico estima desviado de sus propios intereses o reglas de juego que se ha dado, «la gente considera como algo evidente el que se reprima violentamente to distinto, lo discrepante. Pero en qué medida existe en un Estado de derecho una facultad para esto es el verdadero problema, que de antemano no puede resolver la concepción preventivo-especial, porque cae fuera de su campo visual.s ${ }^{77} \mathrm{El}$ otro interrogante, que viene a constituit el teverso de la medalla, es el referente al de la readaptación social del peligroso. Punto que al igual que el otro carece de toda fundamentación de legitimidad, salvo aquella que se basa en la autotidad del grupo hegemónico. "Así resulta altamente incierto el saber cuál es el modelo de sociedad a la que la finalidad de readaptación — se habla de readaptación social-- debe entenderse referida. No parece que éste puede venir dado por la sociedad concreta hoy existente en atención al censurable axiológico existente en la misma. (t8 $^{78}$ Por eso sorprende que Arno Plack, después de haber desarro-

76. Haffke, a pesar de aspirar a una utopía como quedó expresado en la nota anterior, sin embargo, parte del hombre como un ser asocial (p. 163), en cierto nodo recoge el planteamiento que él hace de que la teoría preventiva general cuenta con la naturaleza «mala» del hombre (p. 65). En verdad, con esto Haffke o se remonta a un concepto metafísico indemostrable o su afixmación carece de todo sentido o su afirmación carece de sentido real, ya que to asocial no es algo innato sino en refetencia a una sociedad dada. Más aún, la asocialidad está en referencia a reglas de un grupo dado y no significa que el pretendido asocial no tenga a su vez sus propias reglas. Más aún, puede suceder que haya un delincuente no «asocial», sino totalmente «social», como es el caso del delincuente económico. En definitiva, estas expresiones de «asocial» y «social» sólo tienen un carácter estigmatizador, pero no un contenido real, exactamente como las palabras «bueno» $y$ «malo».

77. Op. cit., p. 17.

78. Cótdoba Roda, "Culpabilidad y Pena», 1977, Bosch, p. 65. Cfr. también 
llado una excelente crítica a las teorías de la retribución y prevención general, aparezca como un decidido defensor de un derecho de medidas basado en la peligrosidad social del autor. ${ }^{79}$ Cietio que Plack llama Ia aten" ción a que no se confundan sus planteamientos con los de la défense sociale y que más bien es «la sociedad de los buenos y justos la que necesita un tratamiento para volver a acoger sin prejuicio a los que han fracasado frente a su orden jurídico y moral falsos». ${ }^{80}$ Sin embargo, a pesar de ello, queda en pie su inclinación por una entonces incomprensible peligrosidad social del autor y por una en realidad imaginaria transformación de las costumbres o evolución moral: conceptos contradictorios y carentes de contenido.

En suma, ninguna de estas posiciones logra señalar qué es la pena. Hay que reconocer, sin embargo, que la teotía de la tetribución es la que más se acerca a esta problemática en razón de su propio contenido; no así las demás, que en verdad la obvian consciente o inconscientemente, so pretexto de referitse a sus fines. Con ello tanto la primera, por su absolutismo o carácter metafísico, como la segunda, por su índole aparentemente neutral o de indiferencia al respecto, resultan teorías encubridoras de la realidad de la pena. Cierto que se puede decir con razón que la pena es un mal o expresión de la coerción estatal. Con ello, evidentemente, uno se acerca al real significado de la pena, pero elio todavía no es suficiente y no agota su contenido. Ello sólo es posible en la medida en que se plantea claramente la indisolubilidad absoluta entre Estado y pena. Esto es, la pena es un instrumento de aseguramiento del Estado, la pena no es otra cosa que autoconstatación general del Estado, reafirmación de su existencia en forma general (una necesidad para su subsistencia). Por eso mismo, a pesar de todas las declaraciones, son los delitos contra el Estado Los más numerosos y los más graves. ${ }^{81}$ En esto no hay diferencias entre ninguna forma de Estado. La pena surge cuando han fracasado todos Ios controles sociales y por eso mismo es más que un control, es expresión absoluta de su catácter represivo. $\mathrm{X}$, por eso, como control y represión del Estado se manifiesta en la especificación de determinadas relaciones concretas que aparecen desvaloradas por el propio Estado, en cuanto son

Toby, op. cit., pp. 108 y ss., en las cuales hace algunas agudas observaciones formales a la utilización de la voz «tratamiento» en vez de castigo.

79. Op. cit., pp. 118 y ss.; cfr. también «Plädoyer für die Abschaffung des Strafrechts", 1974, List Vetlag, pp. 380 y ss.

80. «Die Gesellschaft...», p. 119; sobre lo primero cfr. «Pläduyer...», pp. 389-390.

81. Basta ver el número de artículos y la gravedad de las penas que el Código Penal Español dedica en relación al Estado, en lo que por to demás no difiere de ningún otro código. 
recogidas por las figuras que establecen las leyes penales. De ahí que to injusto surja siempre como «protección» de bienes jurídicos. Pero esta protección no es más que una función de la pena, en cuanto es sólo una expresión de la autoconfirmación del Estado. Es por eso que el punto central de todo análisis crítico tiene que estar necesariamente radicado en esta función de la pena, que es el primer paso para velar la realidad de la pena y darle un carácter de neutralidad, igualdad distributiva y racionalidad. Sobre este punto de la protección volveremos nuevamente al tratar la función de la pena.

Pero al dilucidar qué es la pena, todavía no hemos explicado todos los aspectos que rodean su problemática. Falta todavía señalar sobre qué descansa la imposición de la pena y los llamados «fines» de ella. Para una concepción absoiuta expiatoria, el fundamento de la imposición de la pena es el poder identificado de Dios y soberano, lo que es indemostrable $y$, en definitiva, sólo un mito. Para una concepción absoluta retributiva, el fundamento de la imposición de la pena es la libertad absoluta del individuo, esto es, si Dios lo hizo libre en forma absoluta, quiere decir que el Estado lo puede castigar si hace mal uso de esa libertad. Como señala Muñoz Conde: «El concepto tradicional de culpabilidad es científicamente insostenible, porque se basa fundamentalmente en un argumento que es racionalmente indemostrable: la capacidad de poder actuar de un modo distinto a como tealmente se hizo. ${ }^{82}$ Lo que ha llevado a Gimbernat Ordeig a expresar en forma extrema que la "culpabilidad no existe». ${ }^{83}$ En la teoría de la prevención general la imposición de la pena aparece ligada a la capacidad de motivación por la pena del hombre (racional o por el miedo), lo cual también es indemostrable y más bien parecería lo contratio. En verdad el «buen» ciudadano no es motivado por la pena, ya que las otras formas de control social to han hecho converger a los fines estatales. Y el «mal» ciudadano justamente no es ni ha sido motivado. Más aún, la pena puede provocar la motivación contraria: la reincidencia en gran medida es una prueba de ello. En ese sentido la pena sólo gratifica al buen ciudadano, ${ }^{84}$ en el sentido de que no se le aplica a él, sino al «mal» ciudadano. La pena es el dios Jano y el «buen» ciudadano se gratifica tanto con una cara como

82. Op. cit., p. 223.

83. Gimbernat Ordeig, «โTiene un futuro la dogmática jurídico penal?», p. 78, en Estudios de Derecho Penal, 1976, Civitas.

84. Cfr. Plack, Arno: «Die Gesellschaft...», pp. 114-115; «Plädoyer..,», pp. 105 y ss.; también Toby, op. cit., pp. 107 y 108; Codđington, op. cit., pp. 343 y ss. A pesar de que Haffke quiere sostener lo contrario, este planteamiento aparece muy claramente en él cuando señala: «Es el hombre medio en situaciones normales el que se deja influir por las amenazas penales.» (Op. cit., p. 80.) 
con Ia otra. El Estado se autoconstata en forma general tanto frente al «buen» ciudadano como frente al «mal» ciudadano. Por otra parte, la teoría de la prevención especial plantea la imposición de la pena sobre la base de ta peligrosidad. Con ello hace radicar todo el problema en el individuo (ya seâ desde un punto de vista biológico o social). Ello también es un mito, pues es imposible demostrar que hay individuos «malos»o «buenos» intrínsecamente, ${ }^{85}$ sino que en tealidad sólo hay malos y buenos conforme a los fines que se ha planteado el Estado. Es la «conciencia colectiva», «consenso nacional suprapartidos», «la conciencia socio-estatal», la que impone la desviación. Luego lo que hay que examinar antes que nada es esa "conciencia» y en seguida cuáles y cómo son las vías de inter" nalización de tal conciencia por parte de los individuos. La prevención especial y la defensa social encubren esta realidad.

La imposición de la pena también está ligada al desatrollo del Estado. Un Estado democrático no puede basarse en ficciones o mitos. La afirmación de ellos sólo puede servir pata impedir cualquier regulación o control de la actividad del Estado, para impedir una discusión y revisión crítica de ella, para permitir la tendencia al totalitarismo y la arbitrariedad. La imposición de la pena sólo puede buscarse en aquello a que ella está teferido, esto es, al bombre en sociedad. ${ }^{86}$ No en los mitos creados en su alrededor para someterlo y alienarlo, sino en su tealidad social, esto es, en su capacidad para ser actor de una relación social, lirego en su responsabilidad dentro de ella. Ello implica tomar en cuenta todas las determinaciones concretas, desde el carácter mismo de la relación social hasta todos los factores que influyen dentro de ella. Esto es lo único posible de constatar. ${ }^{8}$

Pot último nos queda por examinar los llamados fines de la pena. Aquí pareciera que justamente tuviesen plena cabida los fines de la prevención general y especial.

Sin embargo, ambos fines de prevencion son sumamente discutibles. En cuanto a la prevención general, hay casi unanimidad entre los autores, aun entre sus propios defensores, que ciertas penas (pena de muerte) y en reiación a ciertos delitos (delitos económicos, etc.) no tienen efecto

85. Véase supra nota 76.

86. Cfr. Muñoz Conde, op. cit., p. 225.

87. Evidentemente tratar a fondo el problema de la culpabilidad escapa a los límites de este trabajo; sobre esta materia hay una larga y controvertida literatura en el último tiempo. Para una excelente posición de síntesis y de camino de solución a los principales problemas de la culpabilidad, véase: "Culpabilidad y Pena» (Córdoba Roda, 1977); sobre el problema en general, véase Juan Bustos Ramírez y Manuel Valenzuela Bejas, «Derecho Penal Latinoameticano Comparado», t. I, en prensa, Ed. Depalma. 
preventivo general alguno. De ahí, entonces, que sus defensores tengan que atemperar los postulados preventivos generales a un determinado grupo de penas, delitos o autores. ${ }^{89}$ Con lo cual la prevención general en cuanto motivadora general aparece claramente abandonada y reducida a una prevención quizá particular. Y aun esta prevención particular tesulta discutible en cuanto a su eficacia. Chambliss presenta para su defensa, entre alguna de sus investigaciones, la referente a las sanciones por aparcamiento infraccional dentro de un recinto universitario. Pero de su investigación en modo alguno queda dilucidado si la baja en las infracciones se debe a la clase y gravedad de la pena impuesta o sólo a la certeza de su aplicación en virtud del aumento de la dotación de funcionarios y del rigor de los controles. Lo que sí queda claro es que ni una ni otra causa (ni el rigor y/o la certeza de la pena) tuvieron efecto alguno sobre los infractores poco frecuentes.

Otro ejemplo que se utiliza mucho es aquel del apresamiento por siete meses de toda la policía danesa por las tropas de ocupación alemana, lo cual hizo aumentar notablemente los delitos y hacer decir a Hoerster: «Este ejemplo confirma que la pena estatal tiene un efecto intimidatotio. ${ }^{90}$ Parecería una conclusión apresurada, ya que lo único que esto demuestra es que la desaparición de la policía propiamente tal (se puso una "policía de reemplazo») es lo que hizo aumentar la actividad delictiva, esto es, Io que originó la actividad delictiva fue la duda sobre la certeza de la apticación de la pena (falta de eficacia de la nueva policía por presunta inexperiencia). Además, habría que plantearse hasta qué punto la ocupación nazi provocó una duda sobre el Estado mismo danés, esto es, sobre su existencia $y$, por tanto, capacidad de autoconstatación (de ahí, posiblemente, la falta de eficacia también de la nueva policía y de los subsistentes tribunales daneses). En suma, las contraargumentaciones particularizadas y no generales, de los defensores de la prevención general, llevan a un callejón sin salida. Lo único que confirman es la ya antigua comprobación de que el efecto preventivo más bien radica en la certeza y prontitud de la aplicación de la pena, lo que también tiene sus límites, pues puede transformar al Estado democtático en un Estado puramente policial. ${ }^{\text {90 bis }}$

88. Cfr. Chambliss, William, J.: «The Deterrent Infuence of Punishment», p. 197, pp. 203-204.

89. Cfr. Chambliss, op. cit., pp. 197 y s.; Haffke, op. cit., p. 80; Hoerster, op. cit., pp. 373 y s.; Koller, op. cit., pp. 82 y ss.

90. Op. cit., p. 374.

90 bis. Una buena muestra o modelo de ello lo constituyen los supermercados. Para que existan y por sus objetivos, las cosas tienen que estar a disposición de la gente, pero al mismo tiempo sucede que es necesario arbitrar medidas y utilizar personal, para evitar la frecuencia de los hurtos. Sin embargo, ello no puede llegar al 
Pero, además, hay una objeción de fondo a la prevención general, esto es, cómo puede ser un fin (algo beneficioso, utópico, deseable de lograr) algo que implica o la utilización del miedo (o bien terror) o una cuestionable «tacional ponderación costos - beneficios». Difícilmente podrá sostenerse con convicción que un Estado democrático tenga por fin la utilización de los aspectos de motivación inhibitoria más negativos para el ser humano, como son los del miedo o terror, que se contraponen a la esencia misma de lo que es la democracia: su carácter libertario y liberador. Tampoco pareciera satisfactorio hablar de una ponderación racional, ya que ello supone para ser verdad o bien, por una parte, un ser absolutamente racional, lo que es una fícción, o que las circunstancias en su totalidad, en las que se da la ponderación, son absolutamente racionales, lo que constituye un mito, como hemos visto en el desarrollo y evolución del Estado. $Y$ un Estado democrático no puede basarse ni en ficciones ni en mitos.

El fin de prevención especial es igualmente cuestionable. En primer lugar, tesulta tan o más particular que el llamado de prevención general. La cifra oscura ( $\mathrm{y}$ a veces parda, respecto de actividades delictivas conformes al sistema) en el delito implica que realmente la mayoria de los que cometen actos delictivos no queden sujetos a tesocialización. Por otta parte, como sostiene Barbero Santos, aparece «cuestionable, empero, que una pena cuya función es crear inhibiciones sea necesaria cuando el sujeto a quien se impone no es peligroso en absoluto» ${ }^{91}$ Además, es plantear una socialización sin considerar que siempte hay socialización, sólo que a veces discrepante con las pautas de ese Estado. Más aún, que a veces tal socialización es conforme a las metas de ese Estado y sólo discrepante en los medios, to que lleva a sostener a Miguel Bajo Fernández que en el caso del delincuente económico «no se podría cumplit el fin esencial de la pena, con lo que la lógica de toda esta concepsción conduce a excluir de tal castigo al delincuente económicos. ${ }^{92}$ Peto, ya tocando el fondo de esta

límite de suprimir lo que es un supermercado, esto es, de la libre dísponibilidad de las cosas por parte de la gente: no se puede convertir en un supermercado policial. Por otra parte el supermercado es también una clata muestra de lo frágil que son los conceptos de «bueno» y «malo», de «social» y «asocial», de «buen ciudadano o ciudadano notrnal» y «malo o anormal», ya que en el supermercado todos hurtan. También es una clara muestra de la fragilidad de la prohibición penal, y sobre todo cuando choca además con los propios intereses del sistema que es la sociedad de consumo. Por eso no es sorprendente que en Alemania Federal se haya redactado un proyecto para despenalizar este tipo de hurtos.

91. «La reforma penal española en la transición a la democracia», p. 61, en Revue Internationale de Droit Pénal, nr. 1, 1978 (49 année).

92. «Derecho Penal Económico aplicado a la actividad empresarial», 1978, Civitas, pp. $80-81$. 
posición, como se ha recalcado por Córdoba y Roxin, ${ }^{93}$ resultaría teconocer como fin de un Estado democrático la posibilidad de manipulación de los individuos por parte del Estado, con ello la falta de control y rediscusión de éste, ya que las pautas de resocialización son determinadas por él y sus instituciones, lo que puede significar en definitiva el totalitarismo de uno, algunos, o de la mayoría sobre la minoría.

No tiene sentido referirse a las teorías integradoras, ${ }^{94}$ porque como muy bien dice Roxin: "Los efectos de cada teoria no se suprimen en absoluto entre sí, sino que se multiplican» ${ }^{95}$ y tampoco una relativización o particularización de sus efectos salvan las objeciones de fondo que se les hacen.

En verdad, para aclararse en relación a este problema de los fines hay que distinguir entre lo que es la pena y la imposición de la pena. De lo que es la pena, esto es, autoconstatación del Estado, no surge un fin, sino una función. Tal función no es otra que la de "proteger» bienes jurídicos. Es cuestionable qué bienes jurídicos sean los protegidos, esto es, la índole misma de la protección. Lo único claramente cierto es que el Estado protege sus bienes jurídicos; por eso función de autoconstatación, no se trata de una función neutral o totalmente generalizadora. El Estado fija mediante la pena determinadas relaciones sociales, mantiene la estratiffcación social, como forma de autoconstatarse y mantenerse. ${ }^{95}$ bis Por eso, la principal tarea dentro de un Estado democrático, y su diferencia con otras formas de Estado, reside en la constante revisión hasta sus bases mismas de esta función. De ahí también los criterios restrictivos de necesidad (o no necesidad) y racionalidad en relación a esta función. Por eso, los principios de que la protección penal es última ratio, de que el Detecho penal es de carácter lagunario y subsidiario, de que se trata de descriminalizar más bien que de criminalizar. El bien jurídico y con ello lo injusto es la piedra angular de la revisión crítica en un sistema que, como el democrático, persigue una liberación permanente..$^{66}$

93 Córdoba Roda, op. cit., pp. 65 y s.; Roxin, op. cit., p. 17.

94. Ctr. Koller, op. cit., pp. 82 y ss.; Coddington, op, cit., pp. 352 y s.; Hart, H.L.A., op. cit., pp. 368 y ss.; Haffke, op. cit., pp. 162 y ss. También el propio Roxin cae en cierto modo en la integración, si bien trata de salvar la contradicción, planteando una concepción dialéctica, pero que de todos modos hace hincapié en los momentos de prevención general y especial, op. cit., pp. 11 y ss.

95. Roxin, op. cit., p. 19.

95 bis. Es en esa medida que con tazón se puede decir que el Estado y sus instituciones actúan como factor criminógeno.

96. Sobre el bien jurídico en este sentido, cfr. Bustos Ramírez: «Consideraciones en torno al injusto», en Nuevo Pensamiento Penal, 1974; «Política Criminal e In justo», en Revue Internationale de Droit Pénal, 1978, nr. 1. 
En cuanto a la imposición de la pena, parecería difícil hablar de que hay una función ligada a ella, en cuanto tiene un carácter individutal y el hombre es siempre un fin en sí mismo y no un objeto susceptible de manipulación, dentro de un Estado democrático. Luego, aquí sólo se puede hablar de un fin, que coincide con el fin del hombre en un Estado democrático, esto es, un ser crítico y liberado. De lo que se trata, pues, es de lograr que la pena cumpla este fin, aunque como todo fin sea utópico y dif́́cil de lograr, y que al mismo tiempo implique una cierta contradicción con el Estado mismo, en cuanto lo obliga constantemente a abrirse, en el sentido de poner a revisión su propia autoconstatación a través de su función de protección. Pero ésa es la contradicción inherente a todo Estado democrático verdadero.

Hay, pues, una función, de carácter general, ligada a to que es la pena y un fin, ligado a la imposición de la pena. Evidentemente este último tiene a su vez por función limitar a la primera en un doble sentido, esto es, de que toda pena ha de temnover obstáculos a la participación crítica del individuo o, por lo menos, evitar que tal participación sea impedida. Pero, la función de la pena, por ser inherente a to que es la pena, predomina sobre el fin, esto es, puede resultar necesaria como autoconstatación, aunque desde el punto de vista del fin pudiese ser evitada. De ahí que en ese caso el fin sólo limita en cuanto a impedir que la participación crítica sea anulada (caso de los «objetores de conciencia»).

En definitiva, la pena tiene un carácter mucho menos grandioso de lo que se pretende. Por lo anteriormente dicho tampoco tiene sentido una diferenciación entre penas y medidas, lo que sólo es producto de una determinada etapa histórica, que en la actualidad ha quedado superada. La pena está ligada a lo que es el Estado y ello implica analizar su evolución, su estructura y su base socio-económica. Sólo a partir de ello se puede realmente avanzar en la práctica a la configuración futura de la pena, en un sentido constantemente progresivo (que ya ha borrado la ficticia frontera entre pena y medida).

La historia del Derecho penal es la historia del Estado, un largo camino de democratización, que sólo estamos iniciando y que por ello requiere una constante revisión crítica y, al mismo tiempo, implica remover permanentemente mitos, ficciones y alienaciones que impidan esta revisión. ${ }^{97}$

97. Hay que considerar que ya es un avance importante y aproximativo lo que ha sucedido en organizaciones o grupos primarios y en determinados movimientos reivindicativos. La transformación, por influencia también de la nueva pedagogía, del padre-autoridad (también autoconstante en el castigo) en un padre liberador, del maestro-autoridad (también antes autoconstante en el castigo) en un maestro iberador, son prueba de ello en grupos primatios. Los movimientos femeninos, que intentan sacar 
«Papers»: Revista de Sociologia

La historia del Derecho penal es la historia de su abolición, pero al mismo tiempo es la historia del Estado y de su progresiva desaparición.

Juan Bustos - Hernán Hormazábaz

Seminario de Derecho Penal

Facultad de Derecho

Universidad de Barcelona

a la mujer de su condición-objeto, eI movimiento ecológico, que pretende liberar a la naturaleza de su subyugación actual, también son una muestra de ello. En una materia que ha tenido una historia muy paralela a la del Derecho penal, como es Ia siquiatria, también la antisiquiatría ha ido hacia la liberación del «alienado». 